\title{
PERNIKAHAN DINI DAN IMPLIKASINYA TERHADAP PENDIDIKAN ANAK DI DESA KELI KECAMATAN WOHA
}

\author{
Syahru Ramadhan \\ Institut Agama Islam (IAI) Muhammadiyah Bima \\ Email: syahrupgmi05@gmail.com
}

\begin{abstract}
Abstrak
Usia pernikahan yang terlalu muda dapat mengakibatkan meningkatnya kasus perceraian karena kurangnya kesadaran untuk bertanggung jawab dalam rumah tangga serta proses pendidikan secara formal bagi anak tidak berjalan sebagaimana mestinya, hal inilah yang terjadi di Desa Keli Kecamatan Woha Kabupaten Bima. Sebagai pisau analisisnya, maka peneliti menggunakan beberapa teori yang sesuai dengan topik yang diangkat diantaranya tentang tinjauan konsep pernikahan dini dari berbagai aspek dan pendidikan anak. Adapun metodologi penelitian dalam penelitian ini adalah menggunakan penelitian kualitatif dimana penelitian dilakukan berdasarkan pada fakta atau kejadian yang terjadi dilapangan mengenai peernikahan dini dan implikasinya terhadap pendidikan anak. Data dalam penelitian ini bersumber dari data primer dan sekunder dengan tekhnik pengumpulan data menggunakan wawancara, observasi dan dokumentasi. Analisis data dengan menggunakan reduksi data, penyajian data dan penarikan kesimpulan. Adapun hasil temuan dalam penelitian bahwa pernikahan dini memiliki dampak biologis, dampak psikologi dan dampak sosial, dampak psikologi yang biasa dialami oleh anak yang melakukan pernikahan dini adalah adanya rasa ketidak percayaannya terhadap anak yang telah dia lahirkan dan perniakahan dini menyebabkan pendidikan jadi terbengkalai disebabkan karena minimnya pengetahuan, pemahaman dan pengalaman dalam mendidik anak.
\end{abstract}

Kata Kunci: Pernikahan Dini, Pendidikan Anak, Desa Keli

\section{PENDAHULUAN}

$\mathrm{P}$ erkawinan pada umunya dilakukan oleh orang dewasa dengan tidak memandang pada profesi, agana, suku bangsa, miskin atau kaya, tinggal didesa atau di kota. Usia perkawinan yang terlalu mudah meningkatkan kasus perceraian karena kurang kesadaran untuk bertanggung jawab dalam kehidupan berumah tangga bagi suami-istri. Meskipun batas umur perkawinan telah ditetapkan dalam pasal 7 ayat (1) UU no. 1 tahun 74, perkawinan hanya diijinkan jika pihak pria sudah 
mencapai umur 19 tahun dan pihak perempuan sudah mencapai umur 16 tahun (Muliani, 2014).

Pernikahan yang terjadi pada saat ini banyak kita jumpai remaja di usia sekolah melakukan pernikahan bahkan mereka tidak segan untuk menikah meskipun di umur mudah karena juga anak yang putus sekolah di usia wajib sekolah juga akan mempengaruhi penyakit pernikahan dini ini. Di Desa keli khususnya banyak anak-anak remaja yang melakukan pernikahan dini baik pada saat sekolah maupun mereka yang putus sekolah pada usia wajib sekolah, sekitar lebih kurang 15 orang yang melakukan pernikahan dini tiap tahunnya bahkan lebih dari itu.

Dalam menganjurkan umatnya untuk melakukan pernikahan, Islam tidak semata-mata beranggapan bahwa pernikahan merupakan sarana yang sah dalam pembentukan keluarga, bahwa pernikahan bukanlah semata sarana terhormat untuk mendapatka anak yang sholeh, bukan semata cara untuk mengekang penglihatan memelihara fajar atau hendak menyalurkan biologis, atau semata menyalurkan naluri saja, akan tetapi islam memandang bahwa pernikahan sebagai salah satu jalan untuk merealisasikan tujuan yang lebih besar yang meliputi berbagai pengaruh mendasar bagi kaum muslim dan eksistensi umat Islam (H. M. Saleh Karim, dkk, 2014).

Menurut Ahmad A. sebagaimana yang dikutip oleh Muliani mendefinisikan pernikahan adalah melaksanankan aqad (perikatan yang di jalin dengan pengakuan kedua belah pihak antara seorang laki-laki dan seorang perempuan atas dasar keridhoan dan kesukaan kedua belah pihak, oleh seorang wali dari pihak perempuan menurut sifat yang telah di tetapkan syarat untuk menghalalkan hidup serumah dan menjadikan yang seorang condong kepada yang seorang lagi dan menjadikan masing-masing darpadanya sekutu ( teman hidup) (Ahmad A, 2014).

Pernikahan dini diartikan merupakan instituisi agung untuk mengikat dua insan lawan jenis yang masih remaja dalam satu ikatan keluarga. Ada beberapa faktor penyebab pernikahan dini, yaitu faktor pribadi dan faktor keluarga. Dari faktor pribadi remaja adalah karena ingin menghindari dosa (seks bebas), dan ada juga yang karena "kecelakaan". Sedangkan dari faktor keluarga adalah karena paksaan 
orang tua. Dalam pernikahan dini, ada beberapa dampak yaitu kanker leher rahim, neoritis depresi, dan konflik yang berujung perceraian. Pernikahan dini dalam perspektif psikologi adalah tidak menghambat pendidikan. Bahkan bisa menambah motivasi. Yang dikhawatirkan adalah emosi mereka yang masih labil. Namun, jika sang remaja mampu mengendalikan diri, dan bersikap dewasa maka permasalahan tersebut akan terhindar

Namun dalam prakteknya masih banyak kita jumpai perkawinan pada usia dini atau di bawah umur, padahal perkawinan yang sukses membutuhkan kekedewasaan tanggungjawab secara fisik maupun mental untuk bisa mewujudkan garapan yang ideal dalam kehidupan berumah tangga. Dari beberapa hal diatas, peneliti merasa tertarik untuk melakukan penelitian bagaimana dampak perkawinan usia dini dengan menganngkat judul Study Tentang Penikahan Usia Dini Dan Implikasinya Terhadap Pendidikan Anak Di Desa Keli Kecamatan Woha Kabupaten Bima.

\section{TINJAUAN TEORITIS}

\section{Tinjauan Tentang Pernikahan Dini}

Secara umum, pernikahan dini yaitu merupakan instituisi agung untuk mengikat dua insan lawan jenis yang masih remaja dalam satu ikatan keluarga. Remaja itu sendiri adalah anak yang ada pada masa peralihan antara masa anak-anak ke dewasa, dimana anak-anak mengalami perubahan-perubahan cepat di segala bidang. Mereka bukan lagi anak, baik bentuk badan, sikap dan cara berpikir serta bertindak, namun bukan pula orang dewasa yang telah matang. Pernikahan dini adalah pernikahan di bawah usia yang seharusnya belum siap untuk melaksanakan pernikahan (Zulfa Fikriana Rahmah, 2012).

\section{Pengertian pernikahan}

Pernikahan menurut Sajuti Tholib, adalah perjanjian suci membentuk keluarga antara seorang laki-laki dan seorang perempuan. Unsur perjanjian disini untuk memperlihatkan segi kesenjangan dari pernikahan serta menampakkannya pada masyarakat ramai. Sedangkan sebutan suci untuk pernyataan segi keagamaannya dari suatu pernikahan (Sajuti Thalib, 1962). 
Adapun menurut syara' nikah adalah serah terima antara lakilaki dan perempuan dengan tujuan unuk saling memuaskan antara satu sama lainnya dan untuk membentuk sebuah bahtera rumah tangga yang sakinah serta masyarakat yang sejahtera.Para ahli fiqih berkata, zawaj atau nikah adalah akad yang secara keseluruhan didalamnya mengandung kata: inkaah atau tajwij. Menurut ibnu qudamah pada umumnya akad nikah adalah akad tajwij (Sulaiman AlMufarraj, 2003).

Islam melihat pernikahan dengan sebuah pandangan yang indah dan memasukannya kedalam bagian yang terpenting di tatanan kehidupan. Islam juga menempatkan pernikahan pada posisi yang sangat mulia, supaya tujuan dan sasaran menikah tercapai, islam telah mengatur tata cara pernikahan supaya menjadi rahmat dan timbulya kasih sayang.

\section{Konsep Pernikahan Dini}

Pernikahan usia dini adalah pernikahan yang dilaksanakan pada usia yang melanggar aturan undang-undang perkawinan yaitu perernpuan kurang dari 16 tahun dan laki-laki kurang dari 19 tahun. Pernikahan pada usia dini merupakan bentuk kegiatan yang sudah dilaksanakan oleh masyarakat. dipengaruhi oleh banyak faktor dan melibatkan berbagai faktor perilaku. Pernikahan Usia dini sebagai bentuk perilaku yang sudah dapat dikatakan membudaya dalam masyarakat.

Di Indonesia pernikahan dini sekitar 12-20\% yang dilakukan oleh pasangan baru. Biasanya, pernikahan dini dilakukan oleh pasangan usia muda yang rata-rata umurnya antara 15-18 tahun. Secara nasional pernikahan dini dengan pasangan usia di bawah 16 tahun sebanyak 26,95\%. Padahal pernikahan yang ideal untuk perempuan adalah 21-25 tahun sementara laki-laki 25-28 tahun. Karena diusia itu organ reproduksi perempuan secara psikologis sudah berkembang dengan baik dan kuat serta siap untuk melahirkan keturunan secara fisik pun mulai matang. Sementara laki-laki pada usia itu kondisi psikis dan fisiknya sangat kuat, hingga mampu 
menopang kehidupan keluarga untuk melindungi baik secara psikis emosional, ekonomi dan social (Julkifli Abdollah, 2015).

\section{Faktor Terjadinya Pernikahan Dini}

Ada beberapa factor yang mendorong terjadinaya perkawinan usia muda yang sering di jumpai di lingkungan masyarakat kita yakni:

a. Faktor ekonomi

Perkawinan usia muda terjadi karena keadaan keluarga yang hidup digaris kemiskinan, untuk meringankan beban orang tuanya maka anak wanitanya dikawinkan dengan orang yang dianggap mampu.

b. Faktor pendidikan

Rendahnya tingkat pendidikan maupun pengetahuan orang tua, anak, dan masyarakat, menyebabkan adanya kecenderungan melakukan perkawinan di usia muda. Jika seorang anak putus sekolah pada usia wajib sekolah, kemudian mengisi waktu dengan bekerja. Saat ini anak tersebut sudah merasa cukup mandiri, sehingga merasa mampu untuk menghidupi diri sendiri.

c. Faktor telah melakukan hubungan biologis

Ada beberapa kasus, diajukannya pernikahan karena anakanak telah melakukan hubungan biologis layaknya suami istri. Dengan kondisi seperti ini, orang tua anak perempuan cenderung segera menikahkan anaknya, karena menurut orang tua anak gadis ini, bahwa karena sudah tidak perawan lagi, dan hal ini menjadi aib (Zulfa Fikriana Rahmah, 2012).

d. Faktor orang tua

Orang tua khawatir kena aib karena anak perempuannya berpacaran dengan laki-laki yang sangat lengket sehingga segera mengawinkan anaknya.

e. Media masa

Gencarnya ekspose seks di media masa menyebabkan remaja modern kian permisif terhadap seks. Sehinnga banyak anak-anak yang masih dibawah umur malakukan pernikahan dini 
dengan cara kawin lari karena takut orang tua tidak setuju dengan apa yang mereka perbuat.

f. Faktor adat

Perkawinan usia muda terjadi karena orang tuanya takut anaknya dikatakan perawan tua, sehingga segera di kawinkan.

\section{Dampak Pernikahan Dini}

Dampak perkawinan usia muda akan rawan terjadi konflik, kesalapahaman, mengutamakan ego masing-masing, tidak mampu menyelesaikan masalah akhirnya membiarkan masalah tersebut terlarut-larut, disamping itu belum mengetahui hak, tanggung jawab, dan kewajiban antara kedua belah pihak (suami/ istri), baik dalam hubungannya dengan mereka sendiri terhadap anak-anak, maupun terhadap keluarga mereka masing-masing.

Suami istri memikul kewajiban yang luhur untuk menegakkan rumah tangga yang menjadi sendi dasar dari susunan masyarakat. tidak bias di pungkiri pada pasangan suami iiistriyang telah melangsungkan perkawinan di usia muda idak bias memenuhi atau tidak mengetahui hak dan kewajibannya sebagai suami istri. Hak tersebut timbul dikarenakan belum matangnya fisik atau mental mereka yang cenderung keduanya memiliki sifat keegoisan yang tinggi.

\section{Pendidikan Anak}

Menurut Poerbakawatja dan Harahap (1981) pendidikan adalah usaha secara sengaja dari orang dewasa untuk dengan pengaruhnya meningkatkan si anak ke kedewasaan yang selalu di artikan mampu menimbulkan tanggung jawab moril dari segala perbuatannya. Orang dewasa itu adalah orang tua si anak atau orang yang atas dasar tugas dan kedudukannya mempunyai kewajiban untuk mendidik misalnya guru sekolah, pendeta atau kiai dalam lingkungan keagamaan, kepala-kepala asrama dan sebagainya (Zulfa Fikriana Rahmah, 2012).

Jadi, pendidikan merupakan usaha sadar yang dilakukan oleh seseorang kepada orang lain dalam hal mendidik dan memberikan pengajara sesuai dengan kententuan dan memberikan latihan mengenai akhlak, maka pendidikan berarti juga menumbuhkan personalitas 
(kepribadian) serta menanamkan tanggung jawab. Dalam hal mendidik anak, orang tua dari si anak berkewajiban untuk memberikan pengajaran terhadap anak-anaknya, apalagi pendidikan yang berbau islami sangat perlu dan penting untuk di transferkan terhadap anak-anaknya.

Dalam mendidik anak ibarat sebuah barang, dan barang itu harus baik, baik memiliki arti yang cukup memuaskan secara kualitas dan penampilan, sungguh kata baik ingin digapai dalam hal apapun, dalam sebuah perusahaan ingin karyawannya bekerja dengan baik, sehingga produk yang dihasilkan menjadi baik, semua lembaga menginginkan anggotanya bekerja dengan baik, sehingga tujuan dari lembaga bias terwujud dengan baik (Suroso Abdusalam, 2012). Begitu pula dengan semua orang tua menginginkan anak mereka tumbuh menjadi anak yang baik, lebih dari itu orang tua mengunginkan anaknya lebih dari anak yang baik, ebih dari anak yang baik adalah anak-anak yang nantinya bias diharapkan menjadi orang-orang yang sebagaimana dikehendaki oleh sang pencipta-Nya. Hal ini telah di jelaskan oleh Alah SWT dalam qur'an surah adz-dzariyat: 56

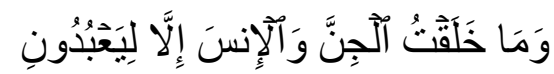

"Dan Aku tidak menciptakan jin dan manusia melainkan supaya mereka mengabdi kepada-Ku”.(QS. Adz-dzariyat: 56) (Al-Qur'an danTerjemahan, 2015)

Tentula untuk membentuk itu, dimulai sebelum anak-anak menjadi orang, maka pendidikan yang semacam ini di mulai dari anak menjadi anak batita, kemudian anak balita kanak-kanak, dan anak sekolah jika dimulai sejak mereka dini maka akan tumbuh anak yang sholeh dan sholehah, beraqidah sholehah dan berkhlak korimah, berprestasi (mampu mengamalkan ilmunya) dan member manfaat bagi lingkungannya.

\section{METODOLOGI PENELITIAN}

Penelitian yang penulis kemukakan di atas, maka pendekatan yang digunakan dalam penelitian ini adalah pendekatan deksriptif kualitatif, yaitu suatu penelitian yang bermaksud untuk membuat deskripsi mengenai situasi-situasi atau kejadian-kejadian (Sumadi Suryabrata , 2010). Pada penelitian kualitatif, data yang dikumpulkan 
umumnya berbentuk kata-kata, gambaran-gambaran, dan kebanyakan bukan berbentuk angka-angka.

Peneliti ini mengadakan pengamatan atau wawancara langsung terhadap obyek atau subyek penelitian, oleh karena itu peneliti terjun langsung ke lapangan dan terlibat langsung. Tujuan menggunakan pendekatan deskriptif kualitatif pada penelitian adalah untuk mendeskripsikan tentang "Study Tentang Pernikahan Dini dan Implikasinya Terhadap Pendidikan Anak Di Desa Keli Kecamatan Woha"

Adapun pengumpulan data diperlukan adanya metode atau cara yang efektif dan efisien, sebab metode memegang peranan penting dalam perolehan data yang akurats dengan demikian penulis menggunakan cara antara lain Observasi, Interview, dokumentasi. Sedangkan instrumen penelitian dalam penelitian ini adalah berdasarkan teknik pengumpula data yang di gunaka, yaitu metode wawancara menggunakan instrumen pedoman wawancara, kemudian metode dokumentasi menggunakan instrumen dokumentasi dan metode observasi menggunakan instrumen observasi atau pengamatan.

\section{HASIL TEMUAN PENELITIAN}

\section{Faktor Penyebab Terjadinya Pernikahan Dini}

\section{Faktor Ekonomi}

Pernikahan Dini merupakan hal yang banyak dilakukan karena dengan factor ekonomi senada juga dengan perkataan bapak Zakariah, S. Pd

"Di masyarakat keli pada umumnya menikahkan anaknya karena adanya laki-laki yang dipandang mapan dalam segi ekonomi dating melamar anaknya oleh kedua orang tua perempuan tersebut walaupun usia anaknya masih sangat muda untuk sebuah pernikahan maka orang tua akan menerima lamaran laki laki yang dating tersebut". (Zakariah, 2015).

Bapak Zakariah, S. Pd.I juga berpandangan bahwa pernikahan di usia dini sah-sah saja selama kedua belah pihak menyetujui syaratsyarat yang telah ditentukan, pada masyarakat kita tidak bisa 
dipungkri dengan menikahkan anak kita di usia dini rentan denga pembicaraan yang tidak menyenangkan, misalnya ada yang terjadi pada si anak perempuan sehingga memaksanya untuk nikah di usia muda, dan juga adanya laki-laki yang dipandang mapan dalam segi ekonomi oleh kedua orang tua perempuan tersebut walaupun usia anaknya masih sangat muda untuk sebuah pernikahan (Zakariah, 2015).

\section{Faktor Pendidikan}

Rendahnya tingkat pendidikan maupun pengetahuan orang tua, anak, dan masyarakat, menyebabkan adanya kecenderungan melakukan pernikahan dini. Peran pendidikan anak-anak sangat mempunyai peran yang besar. Jika seorang anak putus sekolah pada usia wajib sekolah, kemudian mengisi waktu dengan bekerja. Saat ini anak tersebut sudah merasa cukup mandiri, sehingga merasa mampu untuk menghidupi diri sendiri.

Hal ini sesuai dengan pernyataan Bapak Abakar, S. Ag, beliau mengatakan bahwa anak-anak yang melakukan pernikahan dini berawal dari anak putus sekolah pada usia wajib sekolah sehingga anak mengisi waktu kosong dengan bekerja sehinnga anak merasa mampu dan matang untuk hidup mandiri, anak-anak disini juga jika mereka tidak bekerja mereka mengisi kekosongan dengan menjalin hubungan denga lawan jenis dan inilah yang berbahaya jika diluar konrol bisa menyebabkan kehamilan (Abakar, 2015).

\section{Faktor Telah Melakukan Hubungan Biologis}

Ada beberapa kasus, diajukannya pernikahan karena anakanak telah melakukan hubungan biologis layaknya suami istri. Seperti yang di ungkapkan oleh Bapak Zakariah, S.PdI

"Ada beberapa orang tua yang dating melaporkan pernikahan anaknya bahawa anaknya telah melakukan hubungan biologis dengan yang bukan suaminya, maka dengan kondisi seperti ini, orang tua anak perempuan cenderung segera menikahkan 
anaknya, karena menurut orang tua anak gadis ini, bahwa karena sudah tidak perawan lagi, dan hal ini menjadi aib (Zakariah, 2015).

Tanpa mengenyampingkan perasaan orang tua, hal ini sebuah solusi yang kemungkinan di kemudian hari akan menyesatkan anakanak. Ibarat anak sudah melakukan suatu kesalahan yang besar, bukan memperbaiki kesalahan tersebut, tetapi orang tua justru membawa anak pada suatu kondisi yang rentan terhadap masalah. Karena sangat besar di kemudian hari perkawinan anak-anak tersebut akan dipenuhi konflik.

4. Faktor Orang Tua

Tradisi budaya yang masih kental yang menjadi kepercayaan orang tua kita menyebabkan mereka menikahkan anaknya meskipun di usia yang masih sangat mudah seperti yang dikatakan oleh Abdul Khair sebagai berikut.

"saya menikahkan anak saya karena khawatir dengan keadaan anak saya mumpung ada lamaran yang pertama dating apa salahnya saya terima lamaran ini, sebab jika tidak menerima lamaran pertama ini takutnya anak saya tidak akan laku-laku" (Abdul Khair, 2015).

Hal ini juga disampaikan oleh Bapak Jaini yang merupakan orang tua remaja yang melakukan pernikahan dini dia mengatakan bahwa:

" ketakutan yang paling mendalam di hati saya ingin segera menikahkan anak saya karena mereka berpacaran terlalu lengket saya takut akan terjadi hal-hal yang tidak saya ingikan, makanya saya ambil kesimpulan menikahkan saja, karena jika tidak akan menjadi aib dikeluarga jika mereka melakukan halhal yang tidak kami sebagai orang tua inginkan, karena semua orang tua ingin yang terbaik untuk anak-anaknya".

\section{Dampak Pernikahan Dini Terhadap Pendidikan Anak}

1. Dampak Biologis

Secara biologis anak yang melakukan pernikahan dini alat reproduksinya belum matang untuk melakukan hubungan seks 
dengan lawan jenisnya apalagi sampai hamil kemudian melahirkan, untuk melengkapi data ini peneliti melakukan wawancara dengan bidan desa keli ibu juraidah

“ ada salah satu warga kita yang melakukan pernikahan dini yang memprihatinkan dia menikah pada umur 13 tahun namanya siti hawa, dia datang ke puskesmas ketika itu mau melahirkan, akan tetapi sudah tidak kuat lagi untuk melahirkan, karena alat reproduksinya belum matang untuk melahitkan sehingga masih sangat kecil, baik itu kandungan maupun pintu keluarnya sang bayi, sehingga bayi yang ada dalam kandungannya tidak keluar sampai dibawah kepuskesmas kecamatan sampai disana dia menghembuskan nafas terakhirnya, makanya pernikahan di usia yang masih sangat muda akan beresiko tinggi utnuk ibu dan calon ibu" (Juraidah, 2015).

2. Dampak Psikologis

Dampak psikologi yang biasa dialami oleh anak yang melakukan pernikahan dini adalah adanya rasa ketidak percayaannya terhadap anak yang telah dia lahirkan, seperti di ungkapkan oleh bidan desa keli bahwa

"anak yang melakukan pernikan di itu seperti baby blus, mereka tidak percaya bahwa mereka punya anak karena psikis mereka masih sangat kecil dan sebenarnya belum bisa terimah kalau dia punya anak senara psikis anak juga belum siap dan mengerti tentang hubungan sekssehingga menimbulkan trauma psikis yang berkepanjangan dalam jiwa anak yang sulit di sembuhkan" (Juraidah, 2015).

3. Dampak Sosial

Suami istri memikul kewajiban yang luhur untuk menegakkan rumah tangga yang merupakan sendi dasar dari susunan masyarakat, tidak biasa di pungkiri Venomena sosial ini berkaitan dengan factor sosial budaya dalam masyarakat patriarki yang bias gender, yang menempatkan perempuan pada posisi yang rendah dan hanya dianggap seks laki-laki saja 
Bapak Zakariah, S. Pd.I memberikan komentar bahwa "tidak bisa di pungkiri bahwa dampak yang terjadi pada anak yang menikah di usia dini, dampak sosialnya dimata masyarakat, untuk pandangan maupun pendapat masyarakat tentang anak yang nikah pada usia muda pastinya akan sedikit berpikiran negative seperti telah terjadi sesuatu pada anak gadis tersebut walaupun hal tersebut tidak benar-benar terjadi, tudingan miring ataupun ejekan pasti kerap didengar apalagi anak tersebut selain usia masih muda namun juga sedang bersekolah.” (Zakariah, 2015).

4. Implikasinya Terhadap Pendidikan Anak

Pendidikan orang tua terhadap anak adalah sangat dibutuhkan karena baik dan tidaknya anak tergantung pada pendidikan orang tuanya. Pendidikan orang tua adalah yang pertama dan yang utama untuk anak-anaknsya, senada dengan perkataan Zakariah, S. PdI:

"Pendidikan anak adalah sangat penting dan perlu karena generasi tergantung pada orang tuanya, kalau di Tanya tentang implikasi terhadap pendidikan anak jelas ada, anak yang menikah dini sangat minim pemahaman tentang bagaimana cara mendidik anak dengan baik dan benar, banyak anak-anak kita telah salah pendidikan dari orang tua yang menikah dini, orang tua tidaka sabar dalam hal menghadapi anaknya terutama seorang ibunya (Zakariah, 2015).

Seorang ibu merupakan asset terbesar dalam hal mendidik anaknya sehingga besar kemungkinan anak yang dilahirkan menjadi anak-anak yang tidak mau mendengarkan kata-kata orang lain atau apatis, sehingga orang tua adalah orang yang akan menentukan baik dan buruknya generasi selanjutnya.

Kesedihan yang sangat mendalam untuk generasi saat sekarang ini karena pendidikan orang tua sangat tidak diperhatikan sama sekali, padahal pendidikan orang tua itu pendidikan yang pertama dan utama. Seperti peneliti mewawancara Erna remaja yang 
melakukan pernikahan dini pada tanggal 20 April 2015 dia mengatakan bahwa:

"Dalam hal mendidik anak jika anak saya nangis saya cepat marah dan tidak banyk akal untuk menghadapi anak, tidak ada istilah pendidikan seperti ibu guru disekolah, karena memang tidak adanya pengetahuan awal masalah pendidikan anak, mungkin jika ada ilmu terlebih dahulu saya sedikit tidaknya tahu cara bagaimana mendidik anak saya, tapi saya belum berilmu terkait itu " (Erni, 2015)

Penanaman nilai-nilai ibadah kepada anak di kalangan keluarga yang melakukan pernikahan dini masih jauh dari kata sempurna. Sebagian besar di antara mereka masih belum mampu sepenuhnya memberikan pembelajaran, bimbingan, serta keteladanan yang baik bagi anak-anaknya, yang disebabkan olehketerbatasan pengetahuan mereka, dan juga kesibukan mereka masing-masing yang akhirnya menyebabkan kurangnya waktu untuk berkumpul bersama. Meskipun demikian, pada dasarnya mereka memperdulikan pendidikan anak. Namun, karena ketidak mampuan mereka, sehingga mereka menyerahkan kepada pihak sekolah untuk memberikan pendidikan kepada anaknya tersebut.

\section{SIMPULAN}

Keluarga adalah suatu unit masyarakat kecil, maksudnya adalah bahwa keluarga itu merupakan suatu kelompok orang yang merupakan satu kesatuan atau unit yang kumpul dan hidup bersama untuk waktu yang relatif berlangsung terus, karena terikat oleh pernikahan dan hubungan darah, kehidupan keluarga itu mengandung fungsi untuk memenuhi dan menyalurkan kebutuhan emosional para anggotanya, disamping itu juga memberikan kesempatan untuk pensosialisasian para anggotanya, khususnya anak-anak. keluarga sebagai suatu kelompok sosial tidak menyadari dalam suatu kefakuman, melainkan berada ditengah atau setidak-tidaknya bertautan dengan suatu kehidupan sosial dengan budanya.

Dalam hal pernikahan dini ada memang dampak yang akan diterima oleh pelaku tersebut seperti dampak biologis, dampak psikologi 
dan dampak sosial, dampak psikologi yang biasa dialami oleh anak yang melakukan pernikahan dini adalah adanya rasa ketidak percayaannya terhadap anak yang telah dia lahirkan, anak yang melakukan pernikahan dini itu seperti baby blus, mereka tidak percaya bahwa mereka punya anak karena psikis mereka masih sangat kecil dan sebenarnya belum bisa terimah kalau dia punya anak. Tentulah untuk membentuk itu, dimulai sebelum anak-anak menjadi orang, maka pendidikan yang semacam ini di mulai dari anak menjadi anak batita, kemudian anak balita kanakkanak, dan anak sekolah jika dimulai sejak mereka dini maka akan tumbuh anak yang sholeh dan sholehah, beraqidah sholehah dan berkhlak korimah, berprestasi (mampu mengamalkan ilmunya) dan member manfaat bagi lingkungannya.

\section{DAFTAR PUSTAKA}

Abdul Khair. 2015. Wawancara Dengan Tokoh Masyarakat Desa Keli Kecamatan Woha Kabupaten Bima.

Abubakar. 2015. Wawancara Dengan Tokoh Masyarakat Desa Keli Kecamatan Woha Kabupaten Bima.

Ahmad A. 2014. Studi Tentang Pernikahan Usia Dini, Skripsi STKIP BIMA.

Al-Qur'an danTerjemahan Departemen Agama Republic Indonesia, 2005, Jakarta, CV Penerbit.

Erna. 2015. Wawancara Dengan Remaja yang Melakukan Pernikahan Dini di Desa Keli Kecamatan Woha Kabupaten Bima.

Gufran. Wawancara Dengan Guru SMP 3 Filial Keli Kecamatan Woha Kabupaten Bima.

H. M. Saleh Karim, dkk. 2014. Nasehat Pernikahan.Kantor Kementrian Agama.

Http://Zulfa Fikriana Rahmah. Diaksess Tgl 1 Desember 2014. "Resiko Pada Remaja Akibat Pernikahan Dini” Kompas.

Julkifli Abdollah. Diakses 10 Oktober 2015. Pernikahan Usia Dini, http://.Makassar.ac.id.

Juraidah. 2015. Wawancara Dengan Bidan Desa Keli Kecamatan Woha Kabupaten Bima.

Kasman. 2015. Wawancara Dengan Kepala Desa Keli Kecamatan Woha Kabupaten Bima.

Muliani. 2014. Studi Tentang Pernikahan Usia Dini, Skripsi STKIP BIMA.

Sajuti Thalib. 1962. Hokum Kekeluargaan Indonesia, Jakarta, Universitas Indonesia Press. 
Sulaiman Al-Mufarraj. 2003. Bekal Pernikahan, Indonesia, Qisthi Press. Sumadi Suryabrata. 2010. Metodologi Penelitian, Jakarta, Grafindo Persada.

Suroso Abdusalam. 2012. Cara Mendidik Anak Sejak Lahir Hingga TK, Elba Fitrah Mandiri Sejahtera.

Zakariah. 2015. Wawancara Dengan Pegawai Pencatat Pernikahan di Desa Keli Kecamatan Woha Kabupaten Bima.

Zulfa Fikriana Rahmah. 2012. "Resiko Pada Remaja Akibat Pernikahan Dini”. Skripsi STKIP Bima. 